\title{
SES TASARIMININ KOMEDİ FILMLERİNDE ANLATI ÜZERİNE ETKİSİ: AİLE ARASINDA FİLMİ ÖRNEĞİ
}

\author{
Özcan Demir
}

\begin{abstract}
Öz
Sinema filmini meydana getiren görsel ve işitsel ögeler bir arada yapımın anlatısını oluşturmaktadır. Bir sanat olarak ortaya çıktığı andan itibaren sinema, anlatım gücünü geliştirmeye devam etmiştir. Görsel anlatı araçları yanında işitsel olarak diyaloglar, efekt ve müzik kullanımının bu gücün artmasında etkili olduğunu söylemek mümkündür. Bu çalışmada, sinemada anlatının oluşturulmasında sesin etkili olduğu varsayımından hareketle ses tasarımının kökenleri ve temel ögeleri ele alınmıştır. Ses tasarımı ögelerinin belirtilmesinin ardından Aile Arasında (Ozan Açıktan, 2017) isimli komedi filminin bu ögelerin kullanımı bağlamında metinsel çözümlemesi yapılmıştır. Filmin metin analizi bağlamında kamera, mizansen, kurgu, devinim, oyunculuk ve senaryo gibi ögelere ses ile yapılan katkı değerlendirilmiştir. Müziğin kullanımı, diyalogların anlatıya katkısı ve ses ile ilgili olan ögelerin film metni üzerindeki etkisi ele alınmıştır.
\end{abstract}

Anahtar Sözcükler: Sinema, anlatı, komedi, ses tasarımı, müzik. 


\title{
THE EFFECT OF SOUND DESIGN ON NARRATIVES IN COMEDY: THE EXAMPLE OF AİLE ARASINDA
}

\begin{abstract}
The audiovisual elements that form a film combine to construct its narrative. Cinema has improved its narrative power since its beginning as an art. In addition to visual narrative tools, the use of aural elements, including dialogue, effects, and music, has served to increase this power. In this study, the origins of sound design and its elements are discussed, based on the assumption that sound is effective in shaping the narrative. After the elements of sound design are identified, a textual analysis of the musical comedy Aile Arasında (Ozan Açıtan, 2017) shows how these elements contribute to the narrative. They support the work of the camera, the editing, mise en scene, movement, acting, and scenery.
\end{abstract}

Keywords: Cinema, narrative, comedy, sound design, music. 


\section{Giriş}

Sinema, teknolojik bir sihirbazlık gösterisi olarak ortaya çıktığı ilk andan itibaren ses ile birlikte sunulmuştur. Filmler gösterildikleri salonlarda müzik eşliğinde izleyicilerle buluşmuştur. Ses ögesinin görüntünün kaydedildiği film şeridine eşlenmiş biçimde, filmin bir anlatım ögesi olarak kullanılmaya başlandığı ilk yapımları ise 1920'lerin sonunda görmek mümkündür. Bu yapımların ilk örneklerinden, Don Juan (Alan Crosland, 1926) film müziği ve ses efektlerini içermekte ancak diyalog sesleri filmde bulunmamaktayd. Ticari sinemada müzik, efekt ve diyalogların kaydedilerek filmin bir parçası olarak izleyiciye sunulduğu The Jazz Singer (Alan Crosland, 1927) ise ses ögesiyle ilgili tüm elemanların tek şeritte sunulduğu ilk yapım olarak dikkat çekmiştir (Kushins, 2016). Film yapısı açısından bakıldığında izleyici üzerinde çerçevede görülen her nesnenin uygun bir ses ürettiği algısının oluştuğunu söylemek mümkündür. Bunun aksine ses çizgisini oluşturacak elemanlar film yapımı sürecinde ayrı olarak kaydedilebilmekte ve manipüle edilebilmektedir. Bu nedenle, ses de en az diğer teknik film ögeleri kadar geniş bir düzlemde esnektir (Bordwell \& Thompson, 2010, s. 264).

Sahnede görülen her nesnenin bir sesi olduğu ya da olması gerektiği beklentisi popüler sinemada sesin kullanılmasını izleyicinin de talebi haline getirmiştir. Bir dönem bu talebe sanatsal ya da ticari nedenlerle karşı çıkılmaya çalışılmışsa da ticari film sektörü sesli film teknolojisini kullanmaya başlamıştır. Anlatı sinemasının işitsel tamamlayıcısı olarak görülen sesin, sinemada gerçekçiliğin bir parçası biçiminde algılandığını, izleyicinin talebinin de bu eksende gerçekleştiğini söylemek mümkündür. 1920'li yılların sonunda haber filmleri ve kısa filmlerde kullanılan kaydedilmiş ses (recorded sound) ögesi, 1920'li yllların sonunda Amerikan ticari sinemasında uzun filmlerde de kullanılmaya başlanmıştır (Neumeyer, 2011). Klasik Hollywood sineması olarak bilinen dönemde, 1960'lı yıllara kadar farklı kayıt yöntemleri ile sesli Hollywood filmleri üretilmiştir.

Sinema teknolojisinde yaşanan gelişmelere Türk sinema sektörü de kayıtsız kalmamıştır. Yönetmenliğini ve senaryo yazarlığını Muhsin Ertuğrul'un yaptığı İstanbul Sokaklarında (1931) filmi ilk sesli Türk Filmi olarak tarihe geçmiştir. Talat Artemel, Semiha Berksoy gibi dönemin önemli yıldızlarını buluşturan filmde aynı zamanda Mısır ve Yunanistan'dan seçilmiş oyuncular da yer almıştır (Onaran, 1981, s. 187-190). 
Türk sinemasında mono ses izinin sinema filmine dahil edildiği 1930'lu ylllarda dünyanın diğer yerlerinde olduğu gibi sektörün temel ihtiyacı hız ve anlatı netliğiydi. Sinema filminin gerçekçiliğine hizmet ettiği düşünülen sesin bu alandaki katkısı akustik gerçeklik ile sağlanmamiştır (Neumeyer, 2011). 1960'lı ylllar boyunca geniş ekran (widescreen) teknolojisinin kullanıldığı, farklı gösterim ve üretim şartlarının hayata geçtiği ve fon müziğinin kullanıldığı filmlerin gösterimi yapılmaya devam etmiştir. Sesin sinemada estetik bir öge olarak değerlendirilmeye başlanması bir dizi teknolojik gelişmenin ardından mümkün olmuştur. Film yapımında post-production ya da yapım sonrası aşamasındaki ses ile ilgili işlemler 1970'li ylllarda "Dolby Stereo"nun kullanılmaya başlanması ile daha fazla önem kazanmıştır. 1990'lı yıllarda hayata geçen sayısal ses üretimi ve çoğaltma teknolojileri ise bir diğer dönüm noktasını teşkil etmiştir (Bridgett, 2007, s. 30). Dolby teknolojisi, çağdaş ses tasarıminın başlangıcı ve Klasik Hollywood Dönemi'nin sonu olarak da kabul edilmektedir.

"Ses tasarımı" terimi ilk olarak yönetmenliğini Franscis Ford Coppola'nın yaptığı 1979 yapımı Apocalypse Now (Kıyamet) filminde Walter Murch'un üstlendiği görevi tanımlamak için yine kendisi tarafından kullanılmıştır (Anderson, 2015). Walter Murch'ün filmde çok kanallı ses akışı oluşturma amacı ve bunu gerçekliğin farklı bir yorumu olarak filmin kendi ses evreni içerisinde estetik anlamda biçimlendirme çabası; onu film kapsamında yaptığı işi ses tasarımı olarak isimlendirmeye götürmüştür. Murch'e göre yaptığı iş, iç mekân tasarımının ses konusundaki (sonic - sonik) eşdeğeridir. Kendisine çalışmak için sunulan filmin ses ortamı dört tarafı kapalı bir odadır. Murch'un görevi ise sesin bu odayı nasıl dolduracağını belirlemektir (Murch, 2016).

Ses tasarımının ne olduğu konusundaki tespitler, akademik alanda yapılan çalışmalarda filmin akustik evreni üzerinde düşünülmesi gereğini ortaya çıkarmıştır. Sinemada izleyiciye sunulan koşut ses yanında, anlatıya farklı dramatik ve estetik boyutlar katmak için ses kullanımının mümkün olduğu yönetmenler ve film sektörü tarafından görülmüştür. Karakter geliştirme, karakterlerin motivasyonlarının ortaya konulması, atmosfer oluşturulması bağlamında müzikal dizim ve filmin tavrının belirlenmesi açısından ses evreninin oluşturulması ses tasarımının önemli alanlarını teşkil etmektedir. Film anlatısına boyut kazandırılması açısından ses eşsiz bir araç olarak ortaya çıkmıştır. Filmdeki herhangi bir gö- 
rüntü ya da ses, birçoğu metaforik anlamlar bakımından zengin olan, belirsiz sayıda sözel tanımlamaya izin vermektedir (Bordwell, 1989, s. 140). Çağdaş anlatı sinemasında, sesin analiz edilmesi film üzerine kapsamlı çalışmalar yapılabilmesi açısından önemlidir. Yönetmenlerin karakter, çevre ve atmosfer oluşturmada kullandığı görsel kaynaklar yanına sesin de eklenmesi izleyicinin ve analizcinin film konusunda daha sağlam veriler elde edebilmesini sağlamaktadır. Filmin metnini oluşturan, karakter, çekim, kurgu gibi araçların yanında ses de birincil analitik araç olarak kullanılır; bu araçların analiz için kullanılışlı olmalarının nedenlerinden biri de yönetmen ve izleyicinin gerçek ve dikkate değer seçimlerini yansıtmasıdır (Bordwell, 1989, s. 273). İzleyicinin izleme deneyimini geliştiren ses ögesinin kullanımının filmin anlaşılırlığını ve etkisini ne kadar arttırdığının kesin nicel tespitini yapmak güç olsa da sektörel, sanatsal ve akademik açılardan ses tasarımının film yapımındaki anahtar rolünün benimsendiğini söylemek mümkündür.

Türk sineması 2000'li ylllardan itibaren yıllık üretim ve seyirci sayısı bağlamında bir "yeniden doğuş" dönemine girmiştir. Bu yıllarda en popüler örnekler komedi türünde üretilmiştir. Başlangıçta tiyatral yeteneklere dayalı, doğaçlamanın önem kazandığı Türk komedisinde son ylllarda özellikle Recep İvedik gibi popüler örneklerde kentli orta sınıf ile kent hayatına uyum sağlayamamış kesim arasındaki sınıfsal çatışmayı gözlemlemek mümkündür (Pekman \& Tüzün, 2012, s. 11). Sosyolojik farklılıkların ve kültürel ikilemin neden olduğu çatışmaların kaynaklık ettiği komedi anlayışında, film üretiminde ve analizinde ses tasarımının değerlendirmeye alınması sürpriz değildir.

Kişilik yapılarından, mekânsal özelliklerden kaynaklanan çatışmaların vurgulandığı ve güldürünün birer ögesi olarak kullanıldığı popüler komedi anlayışına bir örnek teşkil eden yönetmenliğini Ozan Açıktan'ın, ses tasarımını Ulaş Ağçe'nin yaptığı Aile Arasında (2017) isimli film, bu bağlamda ses tasarımı özellikleri açısından analiz edilmiştir. 2000'li yıllar sonrasında pek çok örneği verilen komedi türü geniş bir evren ortaya koymaktadır. Bu nedenle, temel komedi üslubunu yansıtan ve popüler olmuş bir örneğin evreni temsilen seçilmesine karar verilmiştir.

Çalışma kapsamında öncelikle ses tasarımının tanımı yapılmış ve temel özellikleri vurgulanmış, yapilan literatür taramasıyla bu alandaki görüşler aktarılmıştır. Makalenin ikinci bölümünü teşkil eden örnek film analizinde ise bahsi geçen ses tasarım ilkelerinin Aile Arasında isim- 
li komedi filmindeki uygulaması içerik çözümlemesi yöntemiyle ortaya konulmaya çalışılmıştır. Yapılan çözümlemede, filmin teknik ve estetik ögeleri ses tasarımı bağlamında değerlendirilmiştir.

\section{Anlatı Sinemasının Temel Bir Ögesi Olarak Ses}

Sesli film teknolojisinin ortaya çıkışını takip eden gelişmeler, sesin anlatıyı desteklemek için değiştirilebilmesinin önünü açmıştır. Ses tasarımı, günümüzde işitme duyusunun sinemada yerini bulmasından daha ötesini ifade etmektedir. Ses aynı zamanda izleyicinin dikkatinin çerçevenin herhangi bir noktasına odaklanabilmesini de sağlamaktadır (Bordwell \& Thompson, 2010, s. 266). Walter Murch ses tasarımcisıni; filmin ses efektlerini planlayan, oluşturan ve ses miksini yapan böylece, görüntü yönetmeninin filmin görselliği ile ilgili sorumluluğu aldığı gibi filmin işitsel sorumluluğunu üstlenen kişi olarak tanımlamaktadır (Anderson, 2015). Sonnenchein'a göre (aktaran Johnston, 2014, s. 76) ses tasarımcısı, filmin sonik gerçekliğini sağlamakla görevlidir ve bunun yanında, sonik ortamı oluşturan elemanların hikâyenin ve karakterlerin gelişimine katkıda bulunabileceği alt metni de araması gereklidir. Sesin varlığı sessizliği de film için önemli bir araç haline getirmiştir. Bir filmde yer alan sessiz sahneler gerilimi çok daha fazla arttırabilmekte izleyiciyi çerçeveye odaklanmaya zorlayabilmektedir (Bordwell \& Thompson, 2010, s. 267). Bahsedilen uğraş bir tasarım işidir. Ses tasarımcısı, yaratıcılığı ve teknik bilgisi güçlü bir profesyoneldir (Önen, 2007, s. 357). Bu görüşler ışığında, çağdaş sinema endüstrisinde ses tasarımcısının ses miksajı yapan kurgu bilgisi gelişmiş, ses efektleri üretebilen, film setinde ses kaydı yapan, yaptığı kayıtları filmin dramatik ve estetik yapısı bağlamında yönetmenle yaptığı görüşmeler çerçevesinde değiştirebilen tasarımcı olduğunu söylemek mümkündür.

\section{Sinema Tekniği Bağlamında Ses}

Anlatı sineması, tarihsel olarak belirli normlar çerçevesinde gelişmiştir. 1910'ların ortasından bu yana dramatik eylemin tutarlı bir şekilde oluşturulmuş bir alanda gerçekleşmesi Hollywood stüdyo filmi yapımcılığının bir normudur. Bu alan, süreklilik kurgusu, set elemanlarının devamlılığı ve kabaca tutarlı ses ortamının kurulmasıyla sağlanmıştır (Bordwell, 2007, s. 137). Sinemada ses eşlemesinin sektörel bir tercih olarak ortaya çıkmasının izleyicinin ilgisini çekmek ve gerçekçiliğin sağlanması 
düşüncesiyle bağlantılı olduğunu söylemek mümkündür. Görüntünün yanına diyalogların ve çevre seslerin eklendiği, mucizenin boyutlarının büyüdüğü bir sinema anlayışı oluşturulmuştur. Sinema sanatı için sesin önemi ise izleyicinin salonlara çekilmesi düşüncesinin ötesindedir. Diyalogların kaydedilmesi ile sinemaya yeni bir bilgi aktarım olanağının verilmesi dişında; sesin estetik bir öge olarak sinemaya yeni boyutlar kattığını söylemek mümkündür.

Sinema tarihinde teknik boyutta yaşanan gelişmeler ışığında, ses ögesinin yüzeysel olarak ele alındığı ve onun teknik bir ihtiyaç olarak değerlendirildiği bakış açısının geride kaldığını söylemek mümkündür. İzleyicinin ve yönetmenin sesten beklediği diyalogların ve çevre seslerinin duyulmasının sağlanmasının ötesindedir. Ses ögesinin yüzeysel olarak ele alınması filmin başarısını engelleyebilmektedir (Millerson, 2009, s. 298). Sesin niteliğini kontrol edememek başlangıçtaki asgari olarak hedef olan gerçekçiliğin dahi sağlanamamasını beraberinde getirebilecektir. Ses seviyesinin korunamaması, arka plan seslerinin denetlenememesi sonucu ortaya çıkacak gürültü etkisi ile izleyicinin yönlendirilmesinde zaaflar ortaya çıkabilecektir. Günümüz sinema tekniğinin getirdiği ses perspektifi gibi araçlardan da yararlanılamaması ses kaydının önemsenmemesinin kötü sonuçlarından olacaktır. Sonuç olarak, sinemada ses kaydından beklenen asgari sonuç olan diyalog seslerinin dahi net bir biçimde duyulamaması söz konusu olabilecektir.

\section{Sinema Estetiği Bağlamında Ses}

Ses faktörünün sinema açısından keşfedilmesi, pek çok yeni olanağın önünü açmıştır. Yönetmenin hayal gücünün sınırlarını genişletmesi gereğini ortaya çıkarmıştır. Sinemada ses, müzik ve efektlerin kullanımı, anlatının estetik anlamda gelişmesini sağlamıştır. Ses elemanının eklenmesi ile görüntünün anlatabileceğinin ötesinde mesajların iletilmesinin önü açılmıştır. Ortaya çıkan yeni durum kavramsal olarak da değerlendirilmiştir. Adorno ve Eisler müzik ögesinin sinemanın görsel - işitsel dünyasındaki yerini anlatırken gözün seçici ve aktif olduğuna vurgu yapmıştır. Buna göre: "göz, kesin olan, tekil nesne veya rasyonel kavram ile ilişkilidir. Öte yandan kulak, burjuva rasyonalizasyonuna kolaylıkla uyum sağlamamış, bu şekilde ayrı şeyleri algılamayı daha zor bulmuştur; dolayısıyla, müzikal anlamda acemi bir kulak belirsiz ve pasiftir" (Rosen, 1980, s. 169). Kulağın sesi ayırt etmede, gözün imajları ayırt etmedeki yetisi kadar başarılı olmamasının ya da bunu reddetmesinin izleyicinin 
hayal gücü ile bağlantı kurmanın yolunu açtığını söylemek mümkündür. Başka bir deyişle, ses ögesi sinema filminin daha fazla boyut kazanmasını ve anlatının derinleşmesini sağlamaktadır.

Sinema salonunda ya da film izlenen ortamda sesin dağılımını inceleyen akustik bilimi ile ses tasarımı birbirinden farklı uzmanlık alanlarıdır. Ses tasarımcıları ya da stüdyo kullanıcıları akustik karakteristiklerin işitsel niteliğiyle, stüdyo işlemlerini ve işitsel-görsel eşlemeyi nasıl etkilediğiyle ilgilenmektedir (Millerson, 2009, s. 301). Ses tasarımı, teknolojik gelişmelerle boyut değiştiren sanatsal bir süreçtir. Ses tasarımcısı, yönetmenin hedefleri doğrultusunda film atmosferi ve gösterim ortamı arasındaki işitsel etkileşimin niteliğini belirlemektedir.

James Monaco'ya göre, sinemada sesin yaygınlığı onun en çekici özelliğidir. Hem uzamı hem de zamanı üretir. Ses tasarımında esas olan bir mekân yaratmaktır. Yankı, armoni vb. ya da "ortamın doğal gürültüsü" (room tone) sesin imzasıdır (Monaco, 2002, s. 205). Sessiz sinemada yalnızca görsel referanslarla kurulabilen zaman-mekân ilişkisi, sesli film üretimi ile akustik elemanlar ile de oluşturulabilmiştir. Ses, sinemaya başlangıçta görüntü kadar baskın olarak algılanmayan, fakat sonrasında yapılan araştırmalar ve elde edilen sonuçlarla varlığını kabul ettirmiş bir kanal kazandırmıştır. Sinema üzerine yapılan çalışmalar bu kanalın ifade araçlarını ortaya koymuştur. Christian Metz'e göre, sinemada görsel imge, basılı ve diğer grafikler, konuşma, müzik ve gürültü olmak üzere beş enformasyon kanalı bulunmaktadır (aktaran Monaco, 2002, s. 204). Filmin "sonik evren"ini oluşturan ögeler olan müzik, diyaloglar ve çevre sesleri, görsel ögeler ile birlikte sinemasal gerçekliği oluşturmaktadır. Ses evreni, filmin anlatım boyutuna getirdikleriyle atmosfer yaratabilmekte, farklı zaman ve mekânları birleştirebilmekte ya da ayırabilmekte, arka plandaki çevresel ses (ambient sound) devamlılığını ya da devamsızlığını sağlayabilmektedir (Sözen, 2013, s. 2098). Bu noktada oluşturulan sinemasal gerçeklik, yapımın özgün içeriği ile ilişkilidir. Sonik evreni oluşturan elemanlar yönetmenin isteğine göre görsel bilgiyi destekleyebilmekte ya da ona tezat oluşturabilmektedir. Sonuçta oluşan etki ise filmin dramatik iletisini oluşturmaktadır.

Adorno ve Eisler gibi ses ile görüntünün algılanış biçimleri arasındaki farklllıklara vurgu yapan bir diğer isim de Monaco'dur. Bu farklllığı teknik düzeyde vurgulayan Monaco'ya göre hem ses hem de görüntü çizgisel olarak kaydedilir ve sonradan kurgulanabilir. Ama önemli bir ayrım 
vardır; ses ile görüntüyü algılama tarzımızın zıtlığı yüzünden, görüntü ayrı ayrı kaydedilirken, sesin aralıksız kaydedilmesi gerekir (Monaco, 2002, s. 123). Filmdeki dramatik bütünlüğün sağlanabilmesi açısından birbiri ardına eklenen çekimlerin ses kuşağı aracılığıyla adeta bütünleştirilmesi söz konusudur. Bu şekilde filmin öyküsünün geliştirilmesi ve hikâye akışının oluşturulması sağlanmaktadır. Ses aracılığıyla filmdeki ruh halinin oluşturulması, zaman referansının verilmesi, konum ve dönem bilgisinin izleyiciye aktarılması, film temposunun oluşturulması, heyecan ve diğer etkilerin film anlatısına katılması mümkündür (Bishop \& Sonnenschein, 2012, s. 2).

Ses, insanın çevresini algılayabilmesi için temel referanslardandır. İnsanın çevresinde bulunan canlı ya da cansız her türlü varlığın neden olduğu titreşimlerin bir taşıyıcı tarafından onun kulağına iletilmesi ve bunların beyinde uyandırdığı etkilerdir. Sinemada sesin kullanılması gerçek hayattaki işitsel ögelerin insan eliyle geliştirilmiş araçlarla oluşturulmasıyla mümkün olmuştur. Zamanla gerçeklik kadar, sanatçıların ona ilişkin yorumlarının da yansıtılması yoluna gidilmiştir. Ses bunu başarabilmek için önemli bir öge olmuştur. Çekimlerin ardı ardına eklenmesine dayalı film kurgusunda, içerikle bağlantılı bütünlüğün sağlanması ve uzaysal derinliğin oluşturulması açısından sinema sanatını derinleştirmiştir. Sinemadaki anlık çekimlere dayalı yapının bütünlüğünün sağlanması için zaman içerisinde sürekli olan sese ihtiyaç bulunmaktadır.

Ses teknolojisinde zaman içerisinde yaşanan gelişmeler izleyicilerin beklentilerini yükseltmiştir. Bunu takiben, ses editörlüğü ve daha sonrasında ses tasarımı gibi kabul görmüş iş alanları doğmuştur. Ses tasarımı, film üreticilerinin müziğin, sesin ve efektlerin ifade gücünü anlamasını ve izleyicilerin deneyimlerini geliştirmek için sesin etkilerini kullanarak somut yaratıcı düşünceler oluşturmasını sağlamaktadır (Bishop \& Sonnenschein, 2012, s. 2). Filmlerde yer alan görsel bilginin artması ile izleyicinin bu görüntüleri algılayabilmesi ve gerçekçi olarak kabul edebilmesi için detaylandırılmış ve arttırılmış ses efektlerini deneyimlemesi gerekmektedir (Savage, 2005, s. 333).

Sinemanin ses evrenini oluşturan konuşma, efektler ve müziğin kullanımının eşzamanlı olarak ve aynı amaçlarla kabul gördüğünü söylemek güçtür. Özellikle konuşma ve efektlerin oluşturduğu film ortamına ait diegetik seslerin yanına müzik gibi öykü ortamına dahil olmayan (non-diegetic) bir ögenin eklenmesi sinema gerçekçiliği ile ilgili tartış- 
maların odağında olmuştur. Buna karşın, belgesel sinemada da kaynağı filmde olmayan non-diegetik seslere yer verilebilmiştir (Hale, 2017, s. 18). Sinemada sesin kullanımının en önemli örneklerini oluşturan müzikallerde dahi konuşma, müzik ve şarkının estetik bütünlük içerisinde kullanımı için 1932 yılını beklemek gerekmiştir. Yönetmenliğini Rouben Manaoulian'ın yaptığı Love Me Tonight (Bu Gece Sevişelim) filminin en önemli özelliklerinden birisi de diegetik olarak kurulan müziğin, karakterlerin şarkılarına eşlik eden non-diegetik sese dönüşebilmesinin ilk örneğini sunmuş olmasıdır (Lewis, 2017, s. 10).

Sonik ortam, karakterlerin bir sahnede hissettikleri duyguları iletmek için tasarlanabilir. Müzik bu ortamın ögelerindendir (Johnston, 2014, s. 76). Müziğin kullanımı seyircinin empati, nostalji ve özlemleri için duygusal bir alan yaratmaya yardımcı oluyorsa, müziğin eksikliği de izleyicinin daha farklı türden tepkilerine alan açmaktadır (Caramelea, 2017, s. 1). Filmlerde yer alan sözsüz diyaloglardan da aynı bağlamda söz etmek mümkündür. Bu açıdan, sinema filminin bir ögesi olarak müzik kullanmanın da kullanmamanın da ayrı anlamları olduğunu söylemek mümkündür. Bunun yanında müzik birtakım görsel metaforların işlenmesinde de araç olarak kullanılabilmektedir. Andrew Diey'e göre, filmde seçilen renkler müzikle desteklenmelidir ve soğuk renklerin seçildiği bir film için seçilen sesler de bunu yansıtmalıdır (aktaran Savage, 2005, s. 334).

Koşut ses, sinemada doğal olarak görüntüdeki varlıkların ürettiği sestir ve onların gerçekliğinin bir tamamlayıcısıdır. Ancak, film anlatısı açısından farklı kullanımlarından söz etmek mümkündür. Kontrpuan ses açıklayıcı, eşlemesiz ve görüntüye karşıtlık oluşturan sestir. Konuşma, müzik ya da çevre sesleriyle ilgilenip ilgilenmememiz fark etmez. Bu üç ses zaman zaman farklı olarak koşut ya da kontrpuan, doğal ya da açıklayıcı, eşlemeli ya da eşlemesizdir (Monaco, 2002, s. 206). Filmin görüntüsü ile tezat oluşturan kontrpuan ses çağdaş sinema için önemli bir anlatım aracıdır. Görüntüye ilişkin bir zıtlığın vurgulanması amacıyla tercih edilebilmektedir. Bu çoğu zaman ironik bir yaklaşımın ürünü olabilmektedir. İroninin başat amacı kahkaha ile gelen bir boşalım değil, bir kavrama, ayırt etme, fark etme, özüne ulaşma, bilince çıkarmadır (Derse, 2017, s. 194). Sinemada, ironi oluşturmak amacıyla müzik ve görüntü birlikte kullanılabilmektedir. İçerikle onu savunan tavır arasındaki uyumsuzluk kara mizahın da üslup ögeleri arasındadır. Birçok kara mizah filminde 
müzik, içerik ile absürt bir uyumsuzluk gösterecek şekilde kullanılmaktadır (Ersümer, 2015, s. 315). Çok önemli bir duruma dikkat çekmek amacıyla, onun nasıl hafife alındığını simgeleyen bir müzik parçası kullanımı kontrpuana örnektir.

Sinemada ses ve görüntünün birbirlerine oranla ne kadar değerli oldukları sorusuna ayrılmaz bir etkileşimleri olduğu cevabını vermek uygun olabilecektir. Bu soruya verilen cevap sesin görüntünün destekçisi mi yoksa anlatıyı derinleştiren bir öge olarak mı görülmesi gerektiği sorusunu gündeme getirmektedir. Ses ögesinin sadece görüntüyü açıklamak, onun etkisini arttırmak ve zamansal gerçekliği kurmak için kullanılması ses görüntü iş birliği değil sesin görüntüye esir edilmesidir (Thom, 1999). Günümüzde sinemada ses anlatıya boyut kazandıran bir role sahiptir. Onun öykü anlatımındaki potansiyelinin keşfi estetik bağlamda her ses tasarımcısının ve yönetmenin kat etmesi gereken bir yoldur.

\section{Aile Arasında Filminin Ses Tasarımı Açısından Değerlendirilmesi}

Tük Dil Kurumu Güncel Türkçe Sözlük"e göre edebi anlamıyla anlatı, "Roman, hikâye, masal vb. edebî türlerde bir olay dizisini anlatma biçimi, hikâyeleme, hikâye etme, tahkiye"dir (Türk Dil Kurumu, 2018). Bilim ve Sanat Terimleri Sözlüğü'ne (BSTS) göre ise Roman, öykü, masal, oyun gibi türlerde anlatılan gerçek ya da düşünsel olayların anlatımı"dır (Türk Dil Kurumu, 2018). Sinema filminin başarısını belirleyen temel kıstaslar arasında öykü kadar onun anlatım biçimi de vardır. Sinemaya ait ögelerin doğru ve yerinde kullanımı ile öykünün anlatımındaki başarı sağlanmaktadır. Film sesi, zaman-mekân ilişkisinin kurulmasında, filmin atmosferinin oluşturulmasında ve karakterler hakkında izleyicinin aydınlatılmasında önemli bir ögedir. Karşılaştırma, zıtlıkların abartılı bir biçimde işlenmesi ve mekân vurgusunun güldürü amacıyla kullanıldığı komedi türünde bahsedilen ilişkilerin kurulabilmesi açısından görsel ögeler ile birlikte ses de vazgeçilmezdir. Sesin ironi oluşturmak amacıyla kontrpuan olarak kullanımı diğer film türleri için olduğu kadar komedi filmleri için de geçerlidir.

Zitlıklarla temanın vurgulanmasına dayalı "yan yana yerleştirme" de (juxtaposition) komedi filminin metinsel araçlarındandır. Edebiyat alanında başvurulan "yan yana yerleştirme" yöntemi yazarlar için karakterlerini detaylı bir biçimde resmetmek amacıyla kullanılmaktadır. 
Gerilim yaratma ve edebi etkinin güçlendirilmesi amacıyla tercih edilen bu yöntemde bir karakterin iyiliğinin vurgulanması için hemen yanında kötülüğü ile bilinen başka bir karaktere yer verilebilir. Böylece karakterlerin özellikleri vurgulanmış olur.

Ses tasarımında bahsedilen yöntemlerin kullanılması izleyicinin filmi algılamasını kolaylaştırmakta, komedi filmlerinin izleyici tarafindan takip edilmesini olumlu yönde etkilemektedir. Bu bağlamda ele alınan yönetmenliğini Ozan Açıktan'ın yaptığı Aile Arasında (2017) filmi, işleri kötüye giden avize satıcısı Fikret'in eşinin kendisinden ayrılmak istediğini belirtmesi ve onu evden göndermesiyle başlar. Müzikhol vokalisti Solmaz'ın ise yirmi yılı aşkın süredir birlikte olduğu ve bir de kız sahibi olduğu erkek arkadaşı başka bir kadın için kendisini terk eder. Solmaz'ın kızı Zeynep, Adanalı zengin bir ailenin oğluyla evlenmek istemektedir. Ancak, evlilik ritüellerinin yerine getirilebilmesi ve mazbut bir aile görüntüsü verilebilmesi için Zeynep'in ihtiyacı olan baba ise tesadüf eseri Solmaz ile tanışan ve onlara komşu olan Fikret'tir.

Müzikal karakteri ön planda olan bir komedi filmi olarak Aile Arasında, kültürel anlamda birbirinden farklı olan Solmaz (Demet Evgar) ve Haşmet'in (Erdal Özyağcılar) aileleri arasındaki çatışma ekseninde izleyenleri güldürmektedir. Nevrotik bir tip olan Fiko'nun (Engin Günaydın) temkinli yapısı ile tezat oluşturacak derecede karmaşık bir duruma sürüklenmesi de filmdeki eğlence ve karmaşayı arttırmaktadır. Yanlış anlamalar, sonunda ortaya çıkan yalanlar ve sırlarla örülmüş senaryosuyla Aile Arasinda, komedi filmlerinin karakteristik temposunu yansitmaktadir.

Filmde, ev, müzikhol, kebapçı, villa, avize mağazası, uçak gibi birbirinden farklı mekânlarda yer alan sahneler bulunmaktadır. Tüm bu sahnelerin kurgulanmasında ilgili ortamlara özgü ses efektlerinden yararlanılmıştır. Kapı açılma sesi, anahtar sesi, müzikholde kaydedilmiş şarkının ortama özgü yankısı, evin önüne gelen taksinin motor sesi, taksi kapılarının açılma sesi, avize dükkanındaki konuşmaların ortam akustiğine uygun yankısı, avizelerin şıngırtısı, kebapçıdaki bıçak sesleri ve uçaktaki dahili anons sinyali filmin ses evrenini oluşturan ses kayıtları ve efektler arasindadır.

Komedi filmlerinde senaryo güldürü etkisini oluşturan ve sürdüren temel unsurdur. Filmin senaryosunu yazan Gülse Birsel tarafından oluşturulan tiplerin psikolojik özellikleri ve sosyo-kültürel durumları 
ve amaçları hedeflenen çatışmaların gülmeceye başvurarak işlenmesini desteklemektedir. Filmin diyalog yapısında ve ona eşlik eden Ulaş Ağce'nin tasarımıyla oluşturulan ses evreninde tiplere ilişkin, öyküyü geliştirici bilgiler verilmektedir. Filmin başlangıç bölümünde Fiko'nun Mihriban ile konuşması, Fiko'nun evliliğine sadık ve onu sürdürmeye amaçlı yapısını, Mihriban'ın evliliğini zihnen bitirmiş durumunu anlatmakladır. Solmaz'in müzikhol sanatçısı olduğu bilgisi bu mekândaki çekimle verilirken, vokal olduğu bilgisi Behiye'nin kendisini on beş dakikalık arada şarkı söylemeye davet etmesiyle anlatılmaktadır. Haşmet'in uzun yıllardır kebapçılık yapan, egosu yüksek ve kontrolcü bir aile reisi olduğu bilgisi de ilk sahnede oğlu Kahraman ile restoranında yaptığı sohbette izleyiciye verilir.

Aile Arasında filminde resmedilen zıtlıkları henüz filmin başında görmek mümkündür. Yan yana yerleştirme olarak da algılanabilecek açılışta kullanılan müzik, diyalog ve efektler karakterler ve durumları hakkında bilgi vermektedir. Film, Fiko'nun eve gelişiyle başlar. Fiko'nun eşi Mihriban boş televizyon askısı önünde eşini beklemektedir. Bu sırada, non-diegetik olarak fondan gelen müzik eğlenceli ancak birazdan yaşanacak diyaloğun habercisi olarak gizemlidir.

Elinde kumanda ile kedisini okşayan Mihriban'ın boy çekimine yemek masası ve duvardaki tablonun olmadığı salon görüntüsü eşlik etmektedir. Bu sırada gergin ve eğlenceli müzik fonda sürmektedir. Kapı kilidinde anahtarın dönme efekti ile Fiko'nun kapıdan girişine kesme yapilır:

Fikret: Naber Hanım ne yaptın?

Mihriban: Yani ne yapacağım işte sıkıldım çok...

Fikret: Hava karanlık ya ondandır

Mihriban: Yok, evlilikten sıkıldım.

Fikret, donakalmıştır. Fon müziği biter, sessizlik olur. Sadece Fikret'in ayakkabılarını portmanto üzerine koymasının efekti duyulur. $\mathrm{Bu}$ diyalogda, Fiko evdeki mevcut gerginliği sakinleştirmek için eşinin sıkıntısını hava durumuna bağlamaktadır. Eşinin Fiko kadar politik olmadan doğrudan evlilikten sıkıldığını belirtmesi ise artık birlikte yaşama arzusunun olmadığını açıkça ortaya koymaktadır:

Fikret: Sen ne diyorsun Mihriban?

Mihriban: Hımmm... Boşanacağım ben senden.

Fikret: Yani... Biraz dükkânda işler kötü gitti diye... Bir iki çek senet geri döndü diye... Yani eve haciz geldi diye... Böyle mi olacaktı, ya 


\section{Mihriban?}

Mihriban: Yook Fikret, bak o şekilde düşünme, lütfen. Ama o şekilde.

Fikret: Aaahhh... Yaaa ben... İyi hissetmiyorum ben kendimi.

Mihriban: Sen bu gece nerede kalacaksin?

Fikret: Yaaa... Bavullarını topla git mi diyorsun bana yaaa?

Mihriban: Aaaa.... Estağfurullah olur mu... Öyle şey aşk olsun... Ben topladım senin bavullarını, yatak odasında.

Yine sessizlik olmuştur. Fikret, Mihriban'ın gözünde evliliğin bitmesi için gereken bütün şartları sıralamıştır. İronik olan ise, Fiko için bunların sevgi olan bir evliliğin sürmesine engel olmadığı düşüncesidir. Fikret'in kendisini iyi hissetmediğini söylemesi bile eşinin empati kurmasını sağlamamıştır. Mihriban'ın böyle bir çabası bulunmamaktadır. Eşine olan sevgisinin ve evlilikle ilgili iradesinin bitmiş olduğu vurgusuz bir ses tonu ile eşinin nerede kalacağını sormasıyla ortaya çıkmaktadır. Sahnedeki ruh hali umutsuzluk ve tükenmişliktir. Fondan non-diegetik olarak "Evli Mutlu Çocuklu" şarkısı duyulur. Şarkıdaki ruh hali de bir ilişki ile ilgili hayal kırıklığıdır. Şarkı ile görüntünün birlikteliği sahnenin mesajını vurgularken müzik aynı zamanda müzikhol sahnesine olan bağlantıyı kurmaktadır. Bu bağlantı yalnızca mekânlar arası değil sonradan ortaya çıkacağı üzere duygusal hayatlar arasındaki benzerlikle de ilişkilidir. Mihriban ve Fiko'nun evlilikleri artık bitmek üzeredir, mutlulukları ortadan kalkmıştır ve çocukları da bulunmamaktadır:

Yazgımla kanlı bıçaklı

Kalbim hep alacakll.

Sözleriyle Aile Arasında filminin açllış jeneriği görüntülenir. Jenerik metni müzikhol tabelalarında yer alan neon lambalara benzer karakterle yazılmış, bu şekilde tasarlanmıştır. Müzik devam eder, jenerik ekranı müziğin sürekliliği ile bu kez müzikhol sahnesine bağlanır; Behiye (Ayta Sözeri) şarkısına devam etmektedir:

Hayalim üç kelime

O da şöyle

Evli, mutlu, çocuklu.

Solmaz sahnede Behiye'nin arkasında vokal yapmaktadır. Fikret ve onun sade aile yaşantısıyla pek benzerliği olmayan buna karşın duygusal açıdan benzeşen Solmaz'ın hayatı "Evli Mutlu Çocuklu" şarkısının sürekliliği ile jenerikte bağlanmıştır. İzleyici terkedilmiş bir adam ile müzikholde sahne alan tipler arasındaki bir hikâyeye hazırlanmaktadır. Solmaz, be- 
den dili ve sesini şarkı söylemek için kullanış biçimi ile tipik bir müzikhol vokalistidir. Işıltılı giysileri, pes kullandığı sesi ve zaman zaman izleyenleri eğlenmeye çağıran sözleri ile müzikholdeki eğlencenin sürmesine odaklıdır. Şarkı, müzikhol görüntüleri eşliğinde devam eder, ortamın sesi ve yankısı müzikhol atmosferini ve ses sistemini doğrular biçimdedir.

Behiye dinlenmek üzere sahne arkasına giderken dinleyiciyi eğlendirmeye devam etmek üzere yerini Solmaz'a bırakır. Solmaz'ın söylediği bölüm adeta kendi hayatını anlatmaktadır. Şarkısını uzun yıllardır birlikte yaşadığı Neco'ya (Şevket Çoruh) bakarak okumaktadır. Bir kızları vardır. Sürekli umut etmesine karşın Neco kendisiyle evlenmemektedir. Ancak, kendisi ümit etmeyi bırakamamakta ve onunla birlikte yaşamayı sürdürmektedir. Gerçekte, Neco'nun çizdiği portre güvenilmez bir erkeğe aittir:

Üzenler hep seviliyor

Sevenler hep üzülüyor

Aşka inancım azalıyor

E gitgide hevesim kaçıyor

Kimler kimler yuva kuruyor

Ben niye kuramiyorum

Yazgımla kanlı bıçaklı

Kalbim hep alacaklı

Hayalim üç kelime o da şöyle

Evli mutlu çocuklu.

Solmaz sahnede saz sanatçılarına Neco'nun nerede olduğunu sorar, terkedildiğini öğrenir ve küfrederek eve koşar. Neco evdedir, hasta rolü yapmaktadır. Solmaz arkasını döndüğünde duyulan ayakkabı ve çanta sesleri ise Solmaz'ın Neco'nun kaçtığını anlamasını sağlar. Filmin açılış sahnesinde kullanılan diyaloglar Fikret'in nevrotik, maddi durumu kötüye giden bir eş ve Mihriban'ın zor gününde eşini terk eden sıradan bir ev kadını olduğu bilgisini vermektedir. Filmde, Solmaz müzikhollerde sahne alan, uzun süredir birlikte yaşadığı Neco ile evlenmeyi bekleyen ancak terkedilen kadınken; Neco, Solmaz ile birlikte yaşayan ve onu başka bir kadın için terk eden güvenilmez erkektir. Bu zoraki ilişkide, Neco ve Solmaz'ın Zeynep (Su Kutlu) isminde bir kızları da bulunmaktadır.

Filmin açılış sahnesinde Fikret ve Solmaz'ın birbirine zit dünyaları arasındaki karşıtlık ilişkisini kırmak için "Evli Mutlu Çocuklu" şarkısı duyulur. Efektler ve sessizlik Fikret'in şaşkınlığını anlatmak için kullanılmıştır. Müziğin non-diegetik kullanımı atmosfer oluşturulmasını sağ- 
lamıştır. Bu aşamada, müzik kontrpuan olarak değil öyküyü ilerletici bir biçimde koşut olarak kullanılmıştır.

İzleyenlerin zihninde oluşan ayrı dünyalarda yaşayan insanlar fikri müzik ve koşut kurgu aracılığıyla bağlanmıştır. Karakterlerin karşılaşmaları ise Fikret'in boşanma avukatı ile Solmaz'in Neco yerine yeni bir erkekle tanışmak üzere aynı kafeye gelmelerinde yaşanan karışıklık sonucu olur. Kafede yaşanan tartışma sonucu Fikret bayılır ve Solmaz onu eczaneye getirir. Solmaz yanlış anlama için Fikret'ten özür diler. Kalacak yeri olmayan Fikret'i ev kiralaması için oturduğu ahşap apartmana götürür. Bu noktaya kadar karakterlere ilişkin bilgiler diyaloglarla verilmiştir. Solmaz'ın sinirlendiği, anlarda sessizlik kullanılmıştır. Fikret'in bayıldığı Solmaz'ın panik anında bu atmosferi destekleyici non-diegetik müzik kullanılmıştır. Bu sahne ardından izleyici Solmaz'in namusuna düşkünlüğünü, Fikret'in kötümserliğini öğrenmiştir.

Zeynep ve Emirhan'ın izleyiciyle tanıştırıldığı alışveriş merkezi çıkışı sahnesinde Emirhan, Zeynep'e eşlik ederken "Aşkla yanan gözlerimde imza ihtimal dahilinde" dizelerini mırıldanmaktadır. Fondan gelen şarkının sözleri ve türü Emirhan ve Zeynep'in eğlenmeyi seven, uçarı gençlik hallerinin ve hareketliliklerinin bir yansımasıdır. Filmde kullanılan müzik aracılığıyla bir kez daha karakterler hakkında bilgi verilmiştir. Emirhan, Zeynep'e ailesi hakkında öğrendiklerini anlatırken fondaki şarkı bu kez Zeynep tarafından kısılır ve ciddiyet yine sessizlikle sağlanır. Emirhan, Zeynep'in babasının emniyet müdürü olduğu bilgisine ulaşmıştır ve bu bilgi yanlıştır.

Fikret, Solmaz, Behiye ve Leyla (Derya Karadaş) ile birlikte akşam yemeğine katılır. İçkilerini yudumlarken Behiye'nin söylediği şarkı "Dilek Taşı"dır. Diegetik ses ögesi olarak kullanılan şarkı Solmaz ve Fikret'in içinde bulundukları ruh halini anlatmaktadır. Şarkıdan seçilen bölüm:

Suçumuz neydi ki ayrıldık böyle

Kaybolmuş benliğim, ben ne haldeyim

Efkarım birikti sığmaz içime

Bin sitem etsem de azdır kadere

Gülmeyi unutan yaşlı gözlere

Mutluluktan bir haber ver dilek taşı.

Aile Arasında filminde, kişilerin ruh hallerinin ve sahnelerin atmosferinin oluşturulmasında diegetik ve non-diegetik olarak müzikten 
yararlanılmaktadır. Christian Metz'in vurguladığı gibi müzikal uyum değişik kombinezonlar (tersine çevirmeler, karşıtlıklar, koşutluklar vb.) oluşturulmasına izin verirken aralarından yalnızca kimilerinin karşıt oldukları söylenmektedir (Metz, 2012, s. 47). Filmde de bu bağlamda müzik açıklayıcı ve öyküyü ilerletici bir bağlamda kullanılmaktadır.

Filmde müzik sıkça çekimler arasında köprü kurmak için kullanılmiştır. Emirhan, Zeynep'e evlenme teklif etmeden önce sokaktan ona seslenir, görüntü sokaktaki "benimle evlenir misin?" yazısına ve Emirhan'a kesilir. Emirhan'ın arkası dönük ve yazıdan kendisine çevrinme yapıldığı sırada ise bu tutkulu sevgiyi vurgulamak için non-diegetik ses olarak arabesk müzik ezgileri duyulur. Bu ezgi daha sonra Emirhan ve Zeynep ile ilgili sahnelerde leitmotif olarak kullanilacaktır.

Emirhan Zeynep ile evlenme isteğini dile getirdikten sonra hikâyenin odağına yine Fikret yerleşmektedir. Fikret'in moralinin düzeltilmesi için Solmaz ve yeni komşuları ona yardımcı olur. Bu aynı zamanda Fikret için Joseph Campbell'in belirttiği bir değişim ve erginlenme (2017, s. 93) dönemidir. Yeni komşularının yardımı ve önerileriyle, Fikret gardırobunu ve imajını yeniden biçimlendirmekte, vücudunda kozmetik değişiklikler yaptırmaktadır.

Ses tasarımı açısından değerlendirildiğinde, sesin sinemadaki sürekliliği, kurguda birbirinden bağımsız fragmanlar halinde sunulan aşamaları tek ve destekleyici bir müzikle birleştirmektedir.

Yapımda ses ve görüntünün koşut olarak birbirini desteklediği bir diğer sahne ise Fikret'in artık moralinin düzelip evini aydınlattığı sahnedir. Fikret evini sıcak ışık kaynakları ile tıpkı profesyonel bir avizecinin yapabileceği gibi sıcak bir ev haline getirmiştir. Abajurların açılma efekti görüntü ile bütünleşerek bir anlamda Fikret'in düzelen moralini ve yuva haline gelen evini anlatmaktadır. Solmaz değişimi "Ortam şimdi ortam oldu, ha..." sözleriyle ifade eder.

Tam bu sırada, Zeynep içeri girer, "Anne, Emirhanlar beni istemeye geliyorlarmış" der. Zeynep de bir düğmeye basmıştır, bu efekt de duyulur. Görsel olarak ise onun açtığı ışık Fikret'in pek sevmediği çiğ beyaz ışık veren bir lambadır. Zeynep için aydınlık, Fikret için zor günlerin başlangicidir.

İzleyici Haşmet Kurt ile onun kişiliğini, mesleğini ve ruh halini ortaya koyacak bir biçimde tanıştırılmıştır. Adana'da kebapçılık yapan zengin bir ailenin babasıdır ve sinirli bir kişiliğe sahiptir. Oğlu Kahraman 
(Deniz Hamzaoğlu) ise babası kadar zeki değildir, onun istekleri doğrultusunda hareket etmektedir, ne yapması gerektiği zaman zaman kızgın bir biçimde babası tarafından kendisine hatırlatılmaktadır.

Haşmet'in kontrolcü ve sinirli kişiliği sahnenin açılışında elini masasına kuvvetli bir biçimde vurmasıyla, diyaloglardaki ses tonu ve sözleriyle anlatılmaktadır. Ses tasarımcısı bu etkiyi güçlendirmek için elini masaya vuruşu efektini güçlü bir biçimde işlemiştir. Sahnenin ilerleyen bölümlerinde sert ve sinirli biçimde devam eden konuşmaların aksine; fonda eğlenceli ve mizahi atmosferi devam ettiren bir müziğin kontrpuan kullanımı bulunmaktadır. Haşmet, eşi Mükerrem (Seher Devrim Yakut) tarafından Emirhan'ın evlilik kararı ile ilgili olarak arandığında sert üslubu bir kez daha ortaya çıkmakta, bu kararı benimsemediğini Mükerrem'e belirterek telefonu kapatmaktadır. Oğlu ile yaptığı konuşma şöyle gelişir:

Haşmet Kurt: Bak Kahraman, senin bu kardeşin Emirhan erişkin bir insan yirmi beş yaşında aklı başında bir kişi... kiminle evleneceğine kendinin değil de benim karar vereceğimi bilmiyor mu?

Kahraman: (Onaylayarak) Hiç...

Solmaz, Zeynep ve komşularıyla kızının babası olarak tanıştırabilecek birisini bulmanın zorluğundan bahsederken Fikret bahçeye gelir. Bu sırada, fonda sihir çağrıştıran ve Fikret'in adeta kurtarıcı gibi gözüktüğünü anlatan bir müzik çalmaya başlar. Fikret Solmaz'ın teklifini zor da olsa kabul edecektir. Fikret için en zorlu kısım ise asla rol yapamayan ve yalan söyleyemeyen birisi olarak tüm süreçte Necdet Balcılar olarak yer almaktır.

Emirhan'ın ailesinde durumu ilginç olan bir diğer kişi de Gülümser'dir (Devin Özgür Çınar). Kahraman'ın eşi Gülümser ailenin istenmeyen gelinidir. O da vaktiyle sadece Kahraman'ın isteği ile gelin olarak kabul edilmiştir ancak ailede kabul görmemektedir. Mükerrem, "Boş ver Haşmet biz Kahraman istedi diye Gülümser'i bile aldık..." dediğinde Gülümser'e yapılan reaksiyon çekiminde kendisinin başka yöne baktığı görülür.

Fonda kendisine sarf edilen sözlerle hiçbir ilgisi olmadığını anlatan huzur ve boş vermişliği çağrıştıran bir müzik çalmaktadır. Kontrpuan müziğin sebebinin Gülümser'in aldığı sakinleştiricilerden kaynaklandığı anlaşılır.

Solmaz, Fikret'in kendisine yardım etmeyi kabul etmesi ile ona 
daha fazla güvenmeye başlamıştır. Birlikte eğlenmeye giderler. Solmaz yeni ilişkiler yaşayacaklarına ve daha mutlu olacaklarına inandığını Fikret'e söyler. Bu sırada sözlerini Sezen Aksu'nun yazdığı Rengin'in söylediği "aldatıldık" şarkısı çalmaya başlar. Diegetik müzik eşliğinde Solmaz, Fikret'i dansa kaldırır. Bu şarkı da ona kendi durumunu hatırlatır ve ağlamaya başlar. Kendi deyimiyle yaşadığı katarsis'tir (duygusal boşalma). Bu noktada, güldürü metninin temel ögelerinden birinin ipucu izleyiciye verilmektedir. Tiyatrodan sinemaya aktarılan gülme ya da ağlama yoluyla duygusal boşalma sağlama (Onaran, 1994, s. 183) bir güldürü filminde, ağlayarak yapılmakta, izleyici ile Solmaz arasındaki özdeşim bağı güçlendirilmektedir:
Aldatıldık
Bize neler neler öğrettiler sevdalar üstüne
Aldatıldık aldatıldık sevda böyle değil
Ne masallar ninniler söylediler dünya üstüne
Aldatıldık aldatıldık dünya böyle değil
Ufalana ufalana kaç kuşak
Eridik bu yollarda
Kimimiz yerle yeksan
Kimimiz zorla ayakta

Kolu kanadı kırık kuşlar gibiyiz

Ayrı diyarlarda

Bize saadet nasip şimdi

Uçuk rüyalarda.

Kız isteme Fikret'in Necdet Balcılar olarak ilk büyük sınanmasıdır. Solmaz zaman zaman seçtiği argo sözlerle yine iki aile arasındaki sosyolojik farkllı̆ğı gösterir. Kurt ailesi düğüne ve sonraki sürece ilişkin şartlarını dile getirerek evden ayrılır. Fikret müzikholden döndükleri bir akşam Solmaz'a bir dizi iltifatta bulunur. Aralarında bir yakınlaşma olduğu fondaki romantik müzik ile izleyiciye anlatılır.

Fikret'in diğer sınanması ise Kurt ailesinin güçlü isteği ile düğünün Adana'da yapılmasıdır. Fikret Adana'ya gitmek istemez. Solmaz açısindan her şeyin düzelmeye başlayacağı, sözlerini Sezen Aksu'nun yazdığı Büklüm Büklüm şarkısıyla belirginleşir. Bir vokalist olmasına karşın ilk kez Solmaz için de ışık yapılır:

Büklüm Büklüm 
Sanki seni boğar gibi

Sanki yeniden doğar gibi

Sanki zaman zaman ölür gibi

Acısını, çilesini çekmediysen

Hani büklüm büklüm boynunda

Hani paramparça ruhunda

Hani soran gözlerle kapında

Bekleyen dargin anıların gibi.

Solmaz, şarkıyı kendisine gösterilen nezaket ile daha mutlu olarak söylese de şarkı sözleri kırgınlığını ve üzüntüsünü yansıtmaktadır. Şarkının sonunda evine dönerken Fikret ona hayatının ışığı olduğunu söyler. Bu sirada fonda yine romantik bir müzik sahneye non-diegetik olarak eşlik etmektedir. Fikret Adana'ya geleceğini söyler. Film artık bir erkeğin dostluk ve sevgisi için hiç olmadığı birisi gibi davranacak fedakârlığı yapması, kendisine zıt olsa da bu cesareti göstermesini anlatan bir doğrultuda ilerlemektedir.

Adana turu sırasında gezilen mekânlar Selahattin Sarıkaya ve Halil Atılgan'ın Adana Köprü Başı türküsü eşliğinde gösterilir:

Adana Köprü Başı

Adana köprü başı

Otur saraya karşı

Gel beraber gezelim

Dosta düşmana karşı

Vur çapayı çapayı

Vur kazmayı kazmayı

Kız başına bağlamış

Oyalı da İpek yazmayı

Pamuk içinde çiğit

Elinde altın divit

Hem sararmış hem solmuş

Bir kız için bir yiğit

Vur çapayı çapayı

Vur kazmayı kazmayı

Kız başına bağlamış

Oyalı da ipek yazmayı.

Filmde sıkça yapıldığı gibi izleyicinin mekân algısının oluşması 
için bulunulan yer hakkında bilgi verilmesi aşamasında yapılan kısaltma sonucu ortaya çıkan görsel parçalanma müzik izinin sürekliliği ile bütünleştirilmiştir.

Kına gecesinde, kadınlar ve erkeklerin eğlence mekânları birbirinden ayrı hazırlanır. Bu sahneler birbirlerine paralel olarak kurgulanmıştır. Yapılan kurguda mekân farklılığı çalınan müzik türlerinde de görülmektedir. Kına gecesinde Türk sanat müziği enstrümanları ile orta tempoda şarkılar çalınırken erkek eğlencesinde halay çekilmekte, bir taraftan da klarnet ve keman ile eğlenilmektedir. Daha yüksek tempoda bir eğlence yapılmaktadır. Bu sahnelerde, atmosfer oluşturulmasında müzik etkisi açıkça ortaya konulmaktadır.

Diegetik olarak kullanılan müzik eğlence ortamlarının neşeli atmosferinin oluşturulmasını sağlamaktadır. Solmaz kına gecesinde söylediği şarkı ve beden dili ile bu ortama ait olmadığını yine ortaya koymuştur.

Filmde atmosfer oluşturulması amacıyla sesin kullanımı Haşmet'in babasının mevlidinde de görülmektedir. Mevlitte kadınlar başörtüsü takarken işitsel olarak da ağlayıcı kadınların ağıtları duyulmaktadır.

Kurt ailesi, Haşmet'in babasının ölümünde suçu olmadığı anlaşılan Fikret'in gönlünü almak için onu atış poligonuna götürmeyi tasarlar. Fikret ise bu gezinin kendisini öldürmek için yapıldığını sanmaktadır. Poligona gelindiği anda non-diegetik olarak çalınan müzik gerilimi ortaya koymaktadır. İzleyici bu aşamada gezinin gönül alma amaçlı olduğunu bilmekte iken Fikret bilmemektedir. Çalınan müzik bu anlamda eğlenceli atmosferin aksine bir kontrpuan öge olarak gerilim hissi uyandırır.

Büyükbabasını kaybeden Emirhan en kısa zamanda Zeynep ile evlenmek istemektedir. Zeynep'i kaçırmak için otele gelir. Fikret ile uyurken söylediği şarkı Evli Mutlu Çocuklu'dur. Diegetik olarak kullanılan ses bu kez Emirhan'ın komik durumunu vurgulamaktadır.

Emirhan'ın sabırsızlığı nedeniyle düğün erkene alınır. Tören sürprizlerle doludur. Fikret'in aldatıldığını düşünen eski eşi ve Solmaz'ın eski erkek arkadaşı Neco törene gelir. Tören için yapılan ses tasarımı tipik bir açık hava düğünü atmosferini yansıtmaktadır. Ses sistemi yankısı ve konukların sesleri bu atmosferi oluşturur. Düğün sahnesinde tüm gerçeklerin ortaya çıkması ve düğümün çözülmesine eşlik eden non-diegetik müzikler artan tempoyu vurgulamaktadır. 
Filmin ana fikrinin iletildiği hastane sahnesinde, Fikret Solmaz'a aile olmanın kolay olmadığını anlatırken bu mesajı ve hüznü anlatan bir müzik kullanılmıştır.

Sözlerini Mehmet Duyar'ın yazdığı "Kim bilir?" evlilik töreni umduğu gibi sonuçlanmayan ancak yine de Zeynep ile kavuşan Emirhan ve evliliği biten babasının Solmaz'ın evinde Behiye Hanım'dan dilendiği şarkıdır:

Kim Bilir

Kim bilir bu gidişin dönüşü olacak mi, Ah, nasıl yollarına bakacağım, kim bilir Ufkumda batan güneş bu sabah doğacak mı

Kalben ne kadar dertli olacağım, kim bilir

Kim bilir, kim bilir, kim bilir, kim bilir

Beklemeye tahammül gösterecek mi gönlüm,

Ne malum uzun mudur sensiz geçecek ömrüm

Belki de başucumda, arzu ettiğim ölüm

Hangi yakın zamanda öleceğim kim bilir

Kim bilir, kim bilir, kim bilir, kim bilir.

Filmde atmosfer yine diegetik müzikle oluşturulmuştur. Umudu, hüznü ve beklemeyi anlatan şarkı başta içinde bulunulan ümitsizliği anlatır biçimde düşünülürken Fikret'in gelişinin müjdecisi haline gelmiştir. Tıpkı söylendiğinde bestesi ile hüznü ve neşeyi çağrıştırdığı gibi filmde de gelecek mutluluğun habercisi olmuştur.

Fikret sürpriz bir şekilde mahalleye gelir. Solmaz'a evlenme teklif eder. Film söz ve müziği Ayhan Başkal'a ait olan yanayım şarkısıyla biter. Şarkı, filmin genel neşeli atmosferini ve kavuşan aşıkların ruh halini yansitmaktadır:

Yanayım

Yanayım yanayım, ateşlerde yanayım

O kırmızı dudağından bir öpücük alayım

Sarayım sarayım, kollarımla sarayım

Sen iste yeter ki senin kulun kölen olayım. 


\section{Sonuç}

Ses, anlatım gücünü sürekli geliştiren sinemayı, duygusal ve felsefi aç1dan derinleştiren bir ögedir. Görsel bilginin geliştirilmesinde, filmdeki atmosfer ve ruh halinin izleyiciye anlatılmasında önemli bir araçtır. Aile Arasında filmi kullanılan ses, diyaloglar, efektler, diegetik ve non-diegetik sesler ile anlatının müzik etkisiyle geliştirilmesine örnek teşkil etmektedir. Film ses tasarımıyla karakterlerin motivasyonları ve ruh hallerini de izleyiciye anlatmakta başarılıdır. Müziğin kontrpuan kullanımı ile filmin mizahına ses aracılığıyla katkıda bulunulmuştur.

Yaratıcı yönetmenlerin gelişiyle bütün sanat dallarının anlatım olanaklarının sinemaya taşınması dilini zenginleştirmiştir (Derse, 2017, s. 202). Müziğin ve sesin kullanımını da bu çerçevede ele almaya ihtiyaç bulunmaktadır. Aile Arasında filminde görüntülerin ve olay örgüsünün gücü yanında, diyaloglar, sanatçıların yöresel ağızları kullanmadaki başarısı ve karakterlerini yansıtan dil kullanımları mizahta dil kullanımın önemini ortaya koymaktadır. Efektler, filmde sahnelerdeki atmosferi vurgulamaktadır. Müzikler ise anlatının doğrudan bir aracı halinde tıpkı müzikal filmlerdeki gibi kullanılmıştır. Tüm veriler ışığında Aile Arasında filminin ses tasarımı ile ilgili ögeleri etkin biçimde kullanarak anlatının bir aracı haline getirdiğini söylemek mümkündür.

\section{Kaynakça}

Açıktan, O. (Yönetmen). (2017). Aile Arasında [Film] . Türkiye: BKM Anderson, L. (2015). Film and Sound Design. Oxford Bibliographers. http://www.oxfordbibliographies.com/abstract/document/ obo-9780199791286/obo-97801997912860168.xml rskey=UduFw1\&result=1\&q=Film+and+Sound+Design\#firstMatch (Erişim Tarihi: 4 Ekim 2018).

Anlatı. (2018). Büyük Türkçe Sözlük. Türk Dil Kurumu. http://www.tdk. gov.tr/index.php?option=com_bts\&arama=kelime\&guid=TDK. GTS.5bboedo8b746f2.67521794 (Erişim Tarihi: 29 Eylül 2018).

Bishop, M., \& Sonnenschein, D. Designing with Sound to Enchance Learning: Four Recommendations from the Film Industry. Sounddesign for Pros. https://sounddesignforpros.files.wordpress. com/2012/04/sounddesignmanuscript-19nov20112.pdf (Erişim Tarihi: 27 Ağustos 2018). 
Bordwell, D. (1989). Making Meaning Inference and Rhetoric in the Interpretation of Cinema. Cambridge: Harvard University Press.

Bordwell, D. (2007). Poetics of Cinema. NY: Routledge.

Bordwell, D. \& Thompson, K. (2010). Film Art. NY: McGraw-Hill.

Bridgett, R. (2007). Post-production Sound: A New Production Model for Interactive Media. The Soundtrack, 1(1), 29-39.

Campbell, J. (2017). Kahramanın Sonsuz Yolculuğu (Çev. S. Gürses). İstanbul: İthaki.

Caramelea, A. (2017). The Use and Non-Use of Music in the New Romanian Wave. New Romanian Cinema, 41(2). DOI: 10.3998/ fc.13761232.0041.208.

Derse, S. (2017). Yedi Pencereden Yedinci Sanat Sinema Yazıları. İstanbul: Doruk.

Ersümer, A. O. (2015). Kara Mizah. A. O. Ersümer (Ed.), Sinema Neyi Anlatır (s.297-320). İstanbul: Hayalperest.

Hale, G. E. (2017). Documentary Noise The Soundscape of Barbara Kopple's Harlan County, U.S.A. Southern Cultures, 10-32.

Johnston, N. (2014). Theorizing "Bad" Sound: What Puts the "Mumble" into Mumblecore? The Velvet Light Trap,74 (1), 67 - 79. University of Texas Press.

Juxtaposition.LiteraryDevices. Erişimadresi:https://literarydevices. net/juxtaposition/ (Erişim Tarihi: 24 Eylül 2018).

Kushins, J. (2016). A Brief History of Sound in Cinema. Popular Mechanics. https://www.popularmechanics.com/culture/movies/ a19566/a-brief-history-of-sound-in-cinema/ (Erişim Tarihi: 29 Ağustos 2018).

Lewis, H. (2017). Love Me Tonight (1932) and the Development of the Integrated Film Musical. The Musical Quarterly, 100(1), 3-32. DOI: 10.1093/musqtl/gdxO14

Metz, C. (2012). Sinemada Anlam Üstüne Denemeler (Çev. O. Adanır). İstanbul: Hayalperest.

Millerson, G. (2009). Televizyonda Yapım ve Yönetim. (Ed.M. Kılıç, Çev. D. Y. Kadıoğlu) Ankara: TUR-GEN. 
Monaco, J. (2002). Bir Film Nasıl Okunur? (Çev. E. Yılmaz). İstanbul: Oğlak.

Murch, W. (2016). Walter Murch - Apocalypse Now Sound Design [Video]. Erişim adresi: https://www.youtube.com/ watch?v=FkutX3DWfUc (Erişim Tarihi: 18 Ağustos 2018).

Neumeyer, D. (2011). Music and Cinema, Classical Hollywood. Oxford Bibliographers. http://www.oxfordbibliographies.com/ view/document/obo-9780199791286/obo-9780199791286-0118.xml (Erişim Tarihi: 2 Ekim 2018).

Onaran, A. Ş. (1981). Muhsin Ertuğrul'un Sineması. Ankara: Kültür Bakanlığı.

Onaran, A. Ş. (1994). Türk Sineması.1. Cilt. İstanbul: Kitle.

Önen, U. (2007). Ses Kaүıt ve Müzik Teknolojileri. İstanbul: Çitlembik.

Pekman, C. \& Tüzün, S. (2012). Recep İvedik: "Kahraman"dan "Ürün"e. Galatasaray Üniversitesi İletişim Dergisi, 17, 9-28.

Rosen, P. (1980). Adorno and Film Music: Theoretical Notes on Composing for the Films. Yale French Studies, 60, 157-182.

Savage, J. (2005). Sound2Picture: Developing Compositional Pedagogies From the Sound Designer's World. Music Education Research, 7(3), 331-348.

Sözen, M. (2013). Estetik bir Öğe Olarak Sinemada Ses Tasarımı ve Bir Örnek Film Çözümlemesi. Turkish Studies - International Periodical For The Languages, Literature and History of Turkish or Turkic, 8(8), 2097 - 2109.

Thom, R. (1999). Designing a Movie for Sound. FilmSound.org. http:// filmsound.org/articles/designing_for_sound.htm (Erişim Tarihi: 26 Eylül 2018). 
